\title{
Bone Mineral Densitometry Findings of Children with Newly Diagnosed Celiac Disease
}

\author{
Yeni Tanı Almış Çölyak Hastası Çocuklarda Kemik Mineral Dansitometri Bulgulan
}

\author{
Tansel Ansal Balcı, Zehra Pınar Koç, Hüseyin Aydın Mitil \\ Firat University Faculty of Medicine, Nuclear Medicine Department, Elazig, Turkey
}

\begin{abstract}
Objective: The effect of Celiac Disease (CD) on children's bone is the decrease in bone mineral density (BMD). Osteoporosis is a consequence of this decrease and usually manifests in adult ages. Studies in CD patients generally show that bone density of these patients can be different at the same ages for the same duration of disease. The aim of this study is to investigate the relationship between age and bone mineral density of $C D$ patients at first diagnosis.

Material and Methods: Ninety one patients (M/F: 36/55; age range: 3-16; mean age: 9.6 33.5 ) with diagnosis of CD were included in the study. BMD survey from L1-L4 lumbar spine and total hip of the patients was evaluated at presentation. We evaluated the patients in 3 groups according to their ages: Group 1: pre-school (3-7 years old), Group 2: elementary school (8-1 1 years old) and Group 3: adolescent ( $12-16$ years old). Results were compared using Student's $t$ test and correlation analysis.

Results: The mean disease duration of the patients was 16.4 \pm 16.3 months. Mean height and weight of the patients were $124.8 \pm 17.9$ $\mathrm{cm}$ and $27 \pm 9.3 \mathrm{~kg}$, respectively and height and weight of 37 patients were in $\leq 3$. percentile according to age. The BMD values of both lumbar spine and total hip and Z-scores of lumbar region were in mild correlation with age $(r>0.5)$. There was significant difference between mean ages of patients with low bone mass for chronological age and normal bone densitometry values $(p<0.05)$. There were 27, 36 and 28 patients in Group 1, Group 2 and Group 3, respectively. The difference between mean BMD values of these groups were statistically significant $(p<0.05)$. The mean values of lumbar $Z$ - scores of patients were $-1.08 \pm 1.27,-1.42 \pm 1,-1.86 \pm 1.14$, respectively for these three groups.

Conclusion: Bone mineral densities of CD patients in childhood were lower in elder children at the time of diagnosis. This confirms the opinion that the diagnosis at earlier age results better treatment chance before bone mineral loss appears in CD patients. (MIRT 201 1;20:59-62) Key words: Celiac disease, osteoporosis, bone mineral density, age
\end{abstract}

\section{Özet}

Amaç: Çölyak hastalığının çocuklarda kemik yoğunluğu üzerine etkisi kemik mineral yoğunluğunda azalma seklindedir. Osteoporoz ise bu azalmanın genellikle yetișkin yașlarda ortaya çıkan bir sonucudur. Cölyak hastaları üzerinde yapılan çalıșmalarda aynı yas grubunda ve aynı hastalık süresinde bile kemik yoğunluk kayıplarının farklı olabildiği gösterilmiștir. Bu çalıșmada çölyak hastalığı olan çocuklarda tanı anındaki kemik mineral yoğunluğu değișikliklerini araștırdık.

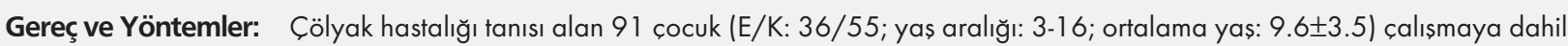
edilmiștir. Tanı anında kemik yoğunluğu L1-L4 vertebral ve total kalça bölgesinden DXA ile ölçüldü. Hastalar yașlarına göre üç grupta değerlendirildi: Grup 1 (okul öncesi: 3-7 yass), Grup 2 (ilkokul: 8- 11 yas) ve Grup 3 (adolesan: 12 - 16 yas). Sonuçlar Student's † testi ve korelasyon analizi ile karșılaștırıldı.

Bulgular: Hastaların ortalama hastalık süresi: $16.4 \pm 16.3$ ay'dı. Hastaların boy ve kilo ortalamaları sırasıyla $124.8 \pm 17.9 \mathrm{~cm}$ ve $27 \pm 9.3 \mathrm{~kg}$ olup hastaların 37 'sinde yașa göre boy ve ağılık değerleri $\leq 3$. persantildeydi. Tüm hastalar birlikte ele alındığında lumbal vertebral ve total kalça

Address for Correspondence: Tansel Ansal Balcı MD, Firat University Faculty of Medicine, Nuclear Medicine Department, Elazig, Turkey E-mail: tansel_balci@yahoo.com

Received: 08.06.2011 Accepted: 26.07.2011

Molecular Imaging and Radionuclide Therapy, published by Galenos Publishing 
bölgesi kemik mineral yoğunluğu ve lumbal bölge Z- skoru değerleri yașla koreleydi ( $r>0.5$ ). Kemik yoğunluğu normal olan ve yașına göre düșük olan hastaların yașları arasında istatistiksel olarak anlamlı fark bulundu (p<0.05). Yașlarına göre gruplandığında Grup 1, Grup 2 ve Grup 3'de sırasıyla 27, 36 ve 28 hasta vardı. Bu üç grubun vertebral ve total kalça bölgesi kemik yoğunlukları arasındaki fark istatistiksel olarak anlamlıydı (p<0.05). Grupların ortalama vertebral z skorları sirasıyla -1.08 $\pm 1.27,-1.42 \pm 1,-1.86 \pm 1.14$ olarak bulundu.

Sonuç: Çocukluk çağındaki çölyak hastalarında tanı anındaki kemik mineral yoğunluğu büyük yas grubunda daha düșük bulunmuștur. Bu durum, ç̈lyak hastalı̆̆ında tanı yașı ne kadar erken olursa kemik yoğunluk kaybı olmadan tedavi sansının o kadar yüksek olacağı görüș̈ünü desteklemektedir. (MIRT 201 1;20:59-62)

Anahtar kelimeler: Çölyak hastalığı, osteoporoz, kemik mineral yoğunluğu, yas

\section{Introduction}

Celiac Disease (CD) is a common inflammatory enteropathy that causes some lifelong complications. One of these complications is osteoporosis and it is associated with increased fracture risk. Patients with CD are generally asymptomatic (1) and osteoporosis and related complications manifest at adult ages $(2,3)$. The important point about $C D$ related osteoporosis is that complete recovery of bone mineral density (BMD) with gluten free diet (GFD) therapy in children is possible but that is not true for adults $(4,5)$. This makes early diagnosis and treatment of these patients necessary. Although most of CD patients have mild symptoms, the loss of bone mineral content of those patients with mild symptoms is fortunately mild, too (6). The fracture risk of symptomatic CD patients was higher than control group but it was not as high as in asymptomatic patients (6). Although we clearly know that $C D$ patients have lower $B M D$ valves than normal population in adulthood, it is not known at which ages this decrease occurs. We aimed to evaluate the trend of BMD alteration of CD patients in childhood before any treatment according to age groups.

\section{Materials and Methods}

\section{Patients}

Ninety one children (36 M, 55 F; age range: 3-16 years; mean: $9.6 \pm 3.5$ years) with $C D$ referred for $B M D$ measurement between November 2006 and May 2009 were retrospectively evaluated. The patients were newly diagnosed as CD and untreated prior to the BMD measurement. We classified patients into three age groups. Group 1: pre-school age, Group 2: elementary school age and Group 3: adolescent age.

\section{Bone Density Measurement}

The BMD was measured by dual energy $x$-ray absorptiometry method (DXA) (LUNAR DPX, Lunar Corp.) from L1-L4 lumbar and total hip regions. BMD values of these regions and Z-score of $L 1-L 4$ lumbar region were obtained. Z-score is the number of standard deviations at system database by which patient's bone density differed from the healthy age matched mean. Z-score $\leq-2$ was considered low bone mass for chronological age and Z-score $>-2$ as normal.

The obtained mean value of precision values of our device was: $0.98 \pm 0.015$.

\section{Statistical Analysis}

The results were compared using Student's t test and the correlation analysis was also performed. $\mathrm{P}<0.05$ was considered statistically significant. The analysis was performed with SPSS version 14

\section{Results}

Mean disease duration was $16.4 \pm 16.3$ months according to the anamnesis. Mean height and weight of the patients were $124.8 \pm 17.9 \mathrm{~cm}$ and $27 \pm 9.3 \mathrm{~kg}$, respectively, and height and weight of 37 patients $(40.7 \%)$ were in $\leq 3$. percentile according to age.

Mean BMD values of lumbar region and total hip region and Z-score of lumbar region in terms of whole group were 0.59 \pm 0.14 and $0.65 \pm 0.15$ and $-1.14 \pm 1.14$, respectively. The BMD values of both lumbar spine and femur and Z-scores of lumbar spine were in correlation with age $(r>0.5)$ (Figure 1,2). There was no correlation between BMD values and disease duration at presentation $(r<0.5)$.

There were 25 patients (mean age: $10.8 \pm 3.2$ years) with low bone mass and 66 patients (mean age: $9.5 \pm 2.6$ years) had normal BMD There was a significant difference between the mean ages of the patients with low bone mass for chronological age and the patients with normal bone densitometry values $(p<0.05)$.

There were 27 (M/F:14/13), 36 (M/F:22/8) and 28 (M/F:13/15) patients in Group 1, Group 2 and Group 3, respectively. Mean values of lumbar and total hip BMD results of the

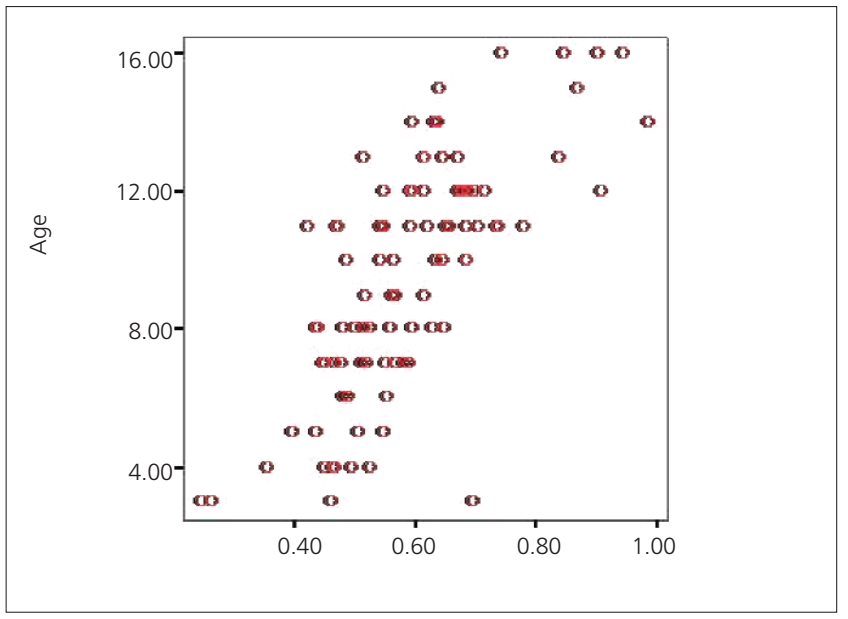

Figure 1. Distribution of BMD levels versus age 


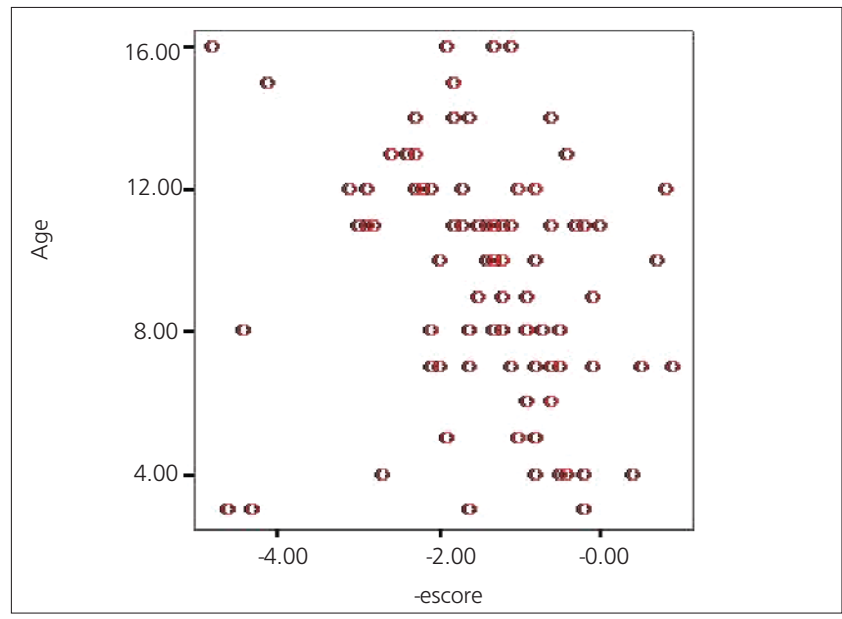

Figure 2. Distribution of Z-scores versus age

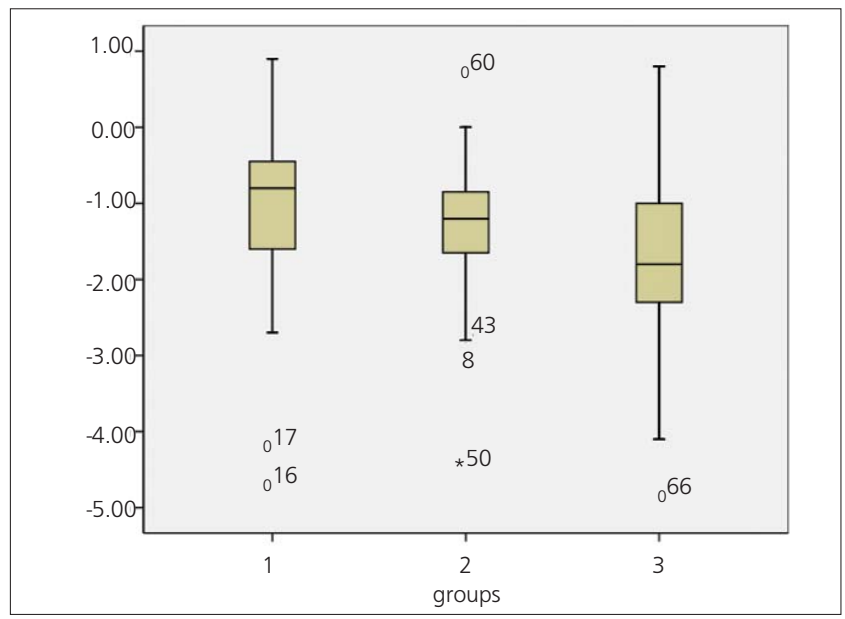

Figure 3. Distribution of Z-scores of three age groups

groups were $0.48 \pm 0.09,0.59 \pm 0.1,0.72 \pm 0.13 ; 0.55 \pm 0.13$, $0.67 \pm 0.12,0.75 \pm 0.11$, respectively. The mean values of vertebral Z-scores of the groups were $-1.08 \pm 1.27,-1.42 \pm 1,-1.86 \pm 1.14$, respectively (Figure 3 ). The difference between mean values of lumbar and total hip BMD results and Z-scores of the groups were statistically significant $(p<0.05)$.

\section{Discussion}

$C D$ causes decreased $B M D$ at adult ages especially if the patients are untreated. Factors that cause reduced BMD are calcium malabsorption, vitamin $D$ deficiency and inflammatory cytokines that result in destruction of bone structure $(7,8)$. Treatment with GFD at earlier ages causes an increase in $\operatorname{BMD}(9,10)$. Some researchers agree that this increase is not complete (11) and disease causes an irreversible osteoporosis. The studies on adult population clearly show that GFD does not recover the effect of the disease on BMD (12).

Since CD patients have an increased risk of osteoporosis, fracture risk was investigated in $C D$ patients. Most researchers concluded that there was an increased risk of fracture in $C D$ patients
$(13,14)$. However no significant difference was found between the patients with fracture compared to those without fracture in terms of Z-scores, serum calcium, 25-hydroxyvitamin D, parathormone and dietary calcium intake (13).

Although $C D$ is usually presented and diagnosed at early childhood (15), our patient population consists of different age groups. This observation made us compare BMD findings of various age groups. There are different studies about BMD at first diagnosis of disease showing low bone density levels in children and adult ages $(16,17)$. Patients who receive appropriate treatment before puberty don nott become osteoporotic at adult age (18). Strict dietary therapy is needed in order to maintain normal bone density outcome (19).

The certain age that osteopenia or osteoporosis occurs in CD patients is not clear. It was demonstrated that both asymptomatic and symptomatic $C D$ patients had lower BMD levels at the time of diagnosis $(20,21)$. Additionally Turner et al. showed that the younger age of $C D$ patients at diagnosis with appropriate therapy was associated with better outcome of BMD (22). Same study mentioned that although they did not intend to assess age related changes of bone density in CD patients, they observed that there was not a significant change in bone mass for age and sex among the 29 patients involved to the study.

In our study we included 91 patients with $C D$ and their mean $Z$-scores were in a wide range $(-1.14 \pm 1.14)$. According to our results there was not necessarily a decrease in Z-scores of CD patients at the time of diagnosis. Mean ages of patients with low bone mass were higher than patients with normal BMD. This finding led us to investigate whether there was a decreasing trend of $B M D$ levels with increasing age groups or not. When the patients were evaluated in three groups according to age (i. e. the first group consisted of the patients in pre-school age, second was elementary school age and third was adolescent age group), there was an increase with increasing ages in terms of mean BMD. As known there is a physiological increase of BMD for growing children. Because of that the important parameter for those patients was Z-score. Although Z-scores of the patients were in a wide range, there was a decrease of $Z$ - scores with increasing age between the groups (Group 1>Group 2>Group 3, in terms of Zscore). This means that bone mineral loss increases proportionally with age in these children.

A limitation of this retrospective study is that we compared different patients' results. We were just aware of that the patients were on starting point without any treatment or diet. If this study is applied to the follow-up BMD results of the same patients for growing ages more meaningful results can be achieved. However in that kind of study, it could be also supposed that the other factors related to time (i.e. dietary factors, treatments etc.) influence the results.

\section{Conclusion}

Age is an important determinant of BMD levels at the time of diagnosis for $C D$ patients. There is a decreasing trend of Z-scores. We suppose that the basal BMD levels and Z-scores of CD patients have to be stated on the earlier ages and be followed up. In this way, early diagnosis of the disease and prevention of bone mineral loss can be achieved as stated in previous reports (23). 


\section{References}

1. Ma“ki M, Mustalahti K, Kokkonen J, Kulmala P, Haapalahti M, Karttunen T, llonen J, Laurila K, Dahlbom I, Hansson T, Höpfl P, Knip M. Prevalence of celiac disease among children in Finland. $N$ Engl J Med 2003;348(25):2517-2524.

2. Bodé S, Hassager C, Gudmand-Hoyer E, Christiansen C. Body composition and calcium metabolism in adult treated coeliac disease. Gut 1991;32(11):1342-1345.

3. Gonzalez D, Mazure R, Mautalen C, Vazquez H, Bai J. Body composition and $B M D$ in untreated and treated patients with celiac disease. Bone 1995; 16(2):231-234.

4. Mora S, Barera G, Beccio S, Menni L, Proverbio MC, Bianchi C, Chiumello $G$. A prospective, longitudinal study of the long-term effect of treatment on bone density in children with coeliac disease. J Pediatr 2001;139(4):516-521.

5. Lunt $\mathrm{H}$, Florkowski CM, Bramwell, Whitehead MR. BMD, Type 1 diabetes, and coeliac disease. Diabetes Care 2001;24(4):791-792.

6. Moreno ML, Vazquez H, Mazure R, Smecuol E, Niveloni S, Pedreira S, Sugai E, Mauriño E, Gomez JC, Bai JC. Stratification of bone fracture risk in patients with celiac disease. Clin Gastroenterol Hepatol 2004;2(2):127-134.

7. Walters JR. Bone mineral density in coeliac disease. Gut 1994;35(2):150 151.

8. Fornari $M C$, Pedreira $S$, Niveloni $S$, González D, Diez RA, Vázquez $H$, Mazure R, Sugai E, Smecuol E, Boerr L, Mauriño E, Bai JC. Pre and posttreatment serum levels of cytokines IL-1B, IL-6, and IL-1 receptor antagonist in celiac disease. Are they related to the associated osteopenia? Am J Gastroenterol 1998;93(3):413-418.

9. Mora S, Barera G, Ricotti A, Weber G, Bianchi C, Chiumello G. Reversal of low bone density with a gluten-free diet in children and adolescents with celiac disease. Am J Clin Nutr 1988;67(3):477-481.

10. Mora S, Weber G, Barera G, Bellini A, Pasolini D, Prinster C, Bianchi C, Chiumello $G$. Effect of gluten-free diet on bone mineral content in growing patients with celiac disease. Am J Clin Nutr 1993;57(2):224-228.

11. Leiva L, Burrows R, Ríos $G$, Bergenfried C, Larrain F, Wenger J, Lillo R, Espinoza J, Pumarino $\mathrm{H}$, Muzzo S. Bone mass in celiac patients. Arch Latinoam Nutr 1996;46(2):128-131.
12. Valdimarsson T, Toss G, Lofman O, Ström M. Three years' follow-up of bone density in adult coeliac disease: significance of secundary hyperparathyroidism. Scand J Gastroenterol 2000;35(3):274-280.

13. Fickling WE, McFarlane XA, Bhalla AK, Robertson DA. The clinical impact of metabolic bone disease in coeliac disease. Postgrad Med J 2001;77(903):33-36

14. Vasquez H, Mazure R, Gonzalez D, Flores D, Pedreira S, Niveloni S, Smecuol E, Mauriño E, Bai JC. Risk of fractures in celiac disease patients: a cross-sectional, case-control study. Am J Gastroenterol 2000;95(1):183 189.

15. Kagnoff M. Overview and pathogenesis of celiac disease. Gastroenterology 2005;128(Suppl 1):10-18.

16. Gonzalez D, Mazure R, Mautalen C, Vazquez H, Bai J. Body composition and bone mineral density in untreated and treated patients with coeliac disease. Bone 1995; 16(2):23 1-234.

17. Corazza GR, Di Sario A, Cecchetti L, Tarozzi C, Corrao G, Bernardi M, Gasbarrini $G$. Bone mass and metabolism in patients with coeliac disease. Gastroenterology 1995; 109(1): 122-128.

18. Tau C, Mautalen C, De Rosa S, Roca A, Valenzuela X. Bone mineral density in children with celiac disease: effect of a gluten-free diet. Eur J Clin Nutr 2006;60(3):358-363.

19. Blazina S, Bratanic N, Campa AS, Blagus R, Orel R. Bone mineral density and importance of strict gluten-free diet in children and adolescents with celiac disease. Bone 2010;47(3):598-603.

20. Kavak US, Yuce A, Kocak N, Demir H, Saltik IN, Gürakan F, Ozen H. Bone mineral density in children with untreated and treated celiac disease. J Pediatr Gastroenterol Nutr 2003;37(4):434-436.

21. Szathmari M, Tulassay T, Arato A, Bodánszky H, Szabó A, Tulassay Z. Bone mineral content and density in asymptomatic children with coeliac disease on a gluten free diet. Eur J Gastroenterol Hepatol 2001;13(4):419-424.

22. Turner J, Pellerin G, Mager D. Prevalence of metabolic bone disease in children with celiac disease is independent of symptoms at diagnosis. J Pediatr Gastroenterol Nutr 2009;49(5):589-593.

23. Capriles VD, Martini LA, Arêas JA. Metabolic osteopathy in celiac disease: importance of a gluten-free diet. Nutr Rev 2009;67(10):599-606. 